\title{
ELEKTRONINĖS PREKYBOS BEI VARTOTOJŲ ELGSENOS POKYČIŲ COVID-19 PANDEMIJOS LAIKOTARPIU LIETUVOJE STATISTINE ANALIŻ
}

\author{
Jolanta Baronaite \\ Eglè Gotautiene \\ Klaipédos valstybine kolegija \\ DOI: https://doi.org/10.52320/svv.v0iVI.189
}

\begin{abstract}
Anotacija
Pasaulị užklupusi COVID-19 pandemija ir karantino priemonès gerokai pakoregavo vartotojų elgseną įsigyjant prekes bei paslaugas internetu. Pastaraisiais metais ir taip ženkliai augęs elektroninès prekybos sektorius padare dar didesni proveržĭ. Karantino laikotarpiu verslui teko persiorientuoti ị pasikeitusią vartotojų elgseną, tokiu būdu el. prekybos rinkoje Lietuvoje atsirado dešimtys naujų internetiniu parduotuvių, o rinkos senbuviai fiksavo kelis kartus didesnius pardavimu (pajamų) augimo tempus. Straipsnyje remiantis mokslinės literatūros šaltiniais ir statistinių duomenų analize nagrinejjamos pirkimo internetu tendencijos, vartotojų pirkimo internetu elgsena bei pirkimo internetu statistinė analizė COVID-19 karantino laikotarpiu. Atlikus elektroninès prekybos dalyvių pardavimų bei pirkimo internetu duomenų analizę, galima teigti, kad Lietuvos gyventojų apsisprendimui pirkti internetu COVID-19 pandemija ir karantinas turèjo didelę įtaką, o ypač tai parodo $2021 \mathrm{~m}$. asmenų apklausų, elektroninės prekybos įmonių finansiniai duomenys.
\end{abstract}

Pagrindiniai žodžiai: elektroninė prekyba, vartotojų elgsena, COVID-19.

\section{Ivadas}

Temos aktualumas. Per pastaruosius keletą metų išmanieji ịrenginiai neabejotinai pakeitè bendravimo, naudojimosi įvairiomis elektroninèmis paslaugomis bei dalijimosi informacija būdus. Laikui bėgant keitėsi ir vartotojų pirkimo ịpročiai. Šiuolaikinių technologijų tobulèjimas paskatino vis didesnị internetinių parduotuvių atsiradimą. COVID-19 krizè paspartino elektroninès prekybos plètrą ịsitraukiant naujoms įmonėms, vartotojams ir produktų tipams. Tai suteiké vartotojams galimybę ịsigyti daug ịvairių produktų, nes tai padaryti namuose buvo patogiau ir saugiau, tuo pačiu suteiké įmonèms galimybę tęsti veiklą, nepaisant kontaktų apribojimų ir karantino. COVID-19 krizè išplètė elektroninès prekybos rinką ịskaitant naujas įmones, vartotojų segmentus (pvz., pagyvenusius žmones) ir produktus (pvz., maisto produktus). Elektroninès prekybos sandoriai iš dalies apèmé ir kasdienio būtinumo produktų, aktualių daugeliui žmonių. Kai kurie iš šių pokyčių el. prekyboje greičiausiai bus ilgalaikiai, atsižvelgiant ị naujų epidemijos bangų galimybę, naujų pirkimo ịpročių patogumą bei paskatas įmonėms investuoti ị naujus pardavimo kanalus.

Yra daug mokslinių straipsnių analizuojančių vartotojų elgesi perkant internetu. Autoriai Prashar, Sai Vijay ir Parsad, (2016); Puspitasari ir kt. (2020) tyrė internetinio pirkimo patogumą, naudą bei saugumą; Aljukhadar ir Senecal (2011) vartotojų psichologines savybes ir patirti perkant internetu, autoriai Ramayah ir kt. (2018) tyre vartotojų ketinimo pirkti internetu modelius; Bauboniené ir Gulevičiūtė (2015) tyrè veiksnius, darančius ịtaką vartotojams apsipirkti internetu. Tačiau dauguma ankstesnių tyrimų buvo atlikti prieš „COVID-19“ viruso plitimą, kyla klausimas, kaip ši pandemija gali turèti įtakos vartotojų elgesiui apsipirkti internetu.

Tyrimo problema. Lietuvoje COVID-19 karantinas dèl judejjimo apribojimo paveikè vartotojų elgseną tiek fizinėse, tiek internetinėse parduotuvėse. Vartotojams didžiąą dienos dali praleidžiant namuose, dėmesys vis dažniau krypo ị apsipirkimą internetu. COVID-19 situacija elektroninę prekybą stumtelèjo ì priekị trejais ar penkeriais metais. Vartotojai, kurie nebuvo pirkę internetu, arba nelabai dažnai naudojo ši apsipirkimo būdą, buvo priversti tai pradèti daryti ar bent jau pabandyti. Ar tokiu būdu formuojasi nauji vartotojų ịpročiai, ar tai karantino pasekmès?

Tyrimo objektas - elektroninès prekybos bei vartotojų elgsenos pokyčiai COVID-19 pandemijos laikotarpiu.

Tyrimo tikslas - išanalizuoti elektroninès prekybos bei vartotojų pirkimo internetu pokyčius COVID-19 pandemijos laikotarpiu. 


\section{Tyrimo uždaviniai:}

1. Pateikti elektroninès prekybos tendencijas bei vartotojų pirkimo internetu elgseną teoriniu aspektu.

2. Išanalizuoti elektroninès prekybos COVID-19 pandemijos laikotarpiu statistinius pokyčius Lietuvoje.

3. Atlikti elektroninès prekybos vartotojų elgsenos COVID-19 pandemijos laikotarpiu analizę.

Tyrimo metodai: straipsnyje taikoma mokslinès literatūros analizę; naudojamas analitinis, sisteminis, apibendrinamasis - aprašomasis metodas. Nagrinejjama, klasifikuojama bei sisteminama mokslinè literatūra. Analizuojamos mokslininkų ižzalgos bei naujausi atlikti tyrimai, elektroninès prekybos dalyvių statistiniai (imonių apyvartos, bankų, interneto naudotojų, tyrimo bendrovių) duomenys.

\section{Elektroninès prekybos tendencijos bei vartotojų elgsenos bruožai}

Šiuo metu nėra vieno unifikuoto ir visuotinai pripažinto elektroninio verslo (toliau vadinama el. verslas) apibrěžimo. Anot Samoliuk (2018) el. verslo santykiuose dalyvauja trys pagrindinès dalyvių grupès: verslas (angl. Bussiness); vartotojai (angl. Customer); valstybinès institucijos (angl. Government). Tarp šių trijų grupių vyksta pagrindiniai el. verslo procesai, o jų ryšys apibrèžiamas kaip modelis. Verslo modelis suprantamas kaip sistema, padedanti palaikyti vertingus kontaktus tarp pirkejjo ir pardavejjo. Pagrinde išskiriami trys modeliai: verslas verslui (B2B), verslas vartotojui (B2C) ir vartotojas vartotojui (C2C) (Niranjanamurthy, Kavyashree, Jagannath, Dharmendra, 2014).

Autorès Išoraitė ir Miniotaitė (2018) savo straipsnyje išskiria papildomus el. verslo rinkos dalyvius: verslas valstybinei institucijai (B2G), valstybine institucija valstybinei institucijai (G2G) bei verslas, valstybinė organizacijos ir vartotojai (B2C ir G2C). Pagal elektroniniu būdu bendraujančiu subjektų vaidmenis el. veikla gali būti skirstoma ị šiuos modelius (Davidavičienè, 2009):

- verslas (B) verslui (B): B2B;

- verslas (B) vartotojui (C): B2C;

- verslas (B) valstybinei institucijai (G): B2G;

- verslas (B) darbuotojui (E): B2E;

- valstybinè institucija $(G)$ valstybinei institucijai: G2G;

- valstybinè institucija (G) verslui (B): G2B;

- valstybinè institucija $(\mathrm{G})$ vartotojui $(\mathrm{C})$ : G2C;

- valstybiné institucija (G) darbuotojui (E): G2E;

- vartotojas $(\mathrm{C})$ vartotojui $(\mathrm{C})$ : $\mathrm{C} 2 \mathrm{C}$;

- vartotojas (C) verslui (B): C2B;

- vartotojas (C) valstybinei institucijai (G): C2G.

Bendraudami tarpusavyje, šie rinkos dalyviai keičiasi įvairių rūšių informacija: informuoja apie savo produktus ir paslaugas, derasi dèl sandorių sąlygų, keičiasi dokumentais, perduoda ir priima prekių užsakymus, skundžiasi apie netinkamas paslaugas ar prekes ir kt. Šių elektroninès rinkos dalyvių santykiai pateikti 1 paveiksle. 


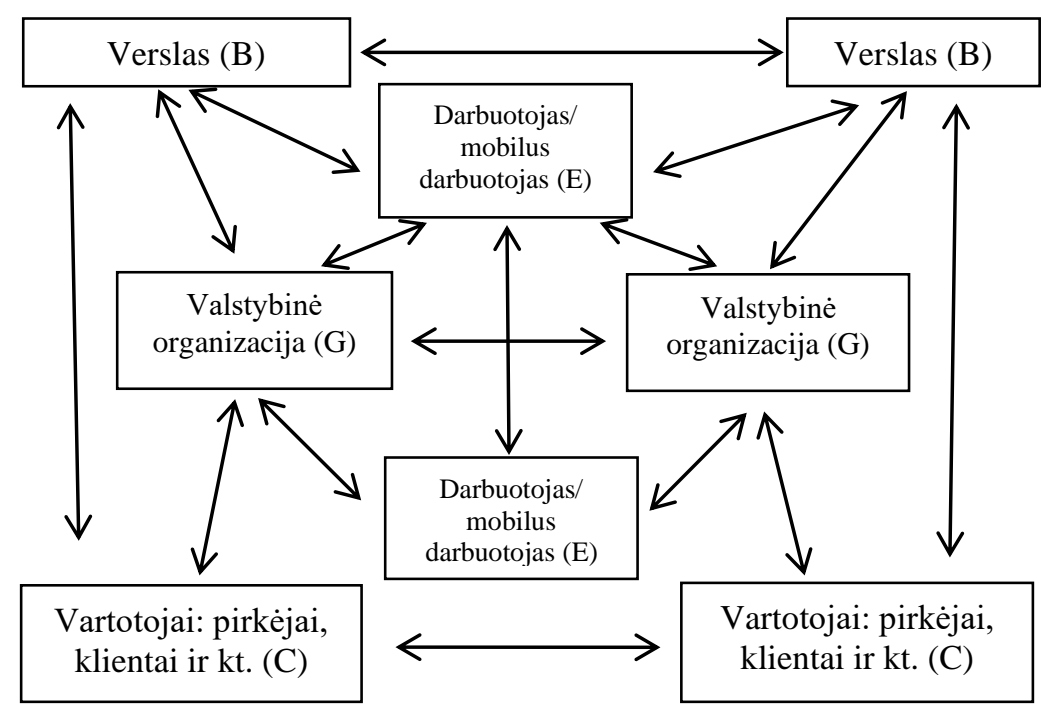

1 pav. Elektroninės veiklos dalyvių santykiai elektroninejje rinkoje

Šaltinis: sudaryta autorių pagal Menasce D., Almeida V. (2000); Davidavičienė V. ir kt. (2009)

Pirkimas internetu seniai pripažintas kaip vienas iš būdų įsigyti produktus ir paslaugas bei greitai tapo itin populiarus. Toks pirkimas suteikia vartotojui daugiau informacijos apie norimus ịsigyti produktus (paslaugas), susipažinti su kitų klientų atsiliepimais bei galimybę palyginti produktus ir jų kainas. Tyrimais buvo įrodyta, kad pirkimas internetu teikia daugiau pasitenkinimo šiuolaikiniams vartotojams, ieškantiems patogumo ir greičio (Katawetawaraks, Wang, 2013). Apsipirkimas internetu ženkliai skiriasi nuo tradicinio - fizinio pirkimo. Kai kurie autoriai (Hasan 2019; Jain, 2020; Išoraitė, Miniotienè, 2018; Alamdari ir kt., 2020) išskiria internetinio pirkimo privalumus ir trūkumus (1 lentelè).

1 lentelè. Pirkimo internetu privalumai ir trūkumai

\begin{tabular}{|c|c|}
\hline Privalumai & Trūkumai \\
\hline $\begin{array}{l}\text { Paprasta ir greita. Galimybė užsisakyti prekę iš bet kurio } \\
\text { pasaulio krašto. }\end{array}$ & Bendravimo ir asmeninių santykių trūkumas. \\
\hline Patogu (dvidešimt keturias valandas per parą). & İsigyta prekė gali būti neatsiųsta ar paslauga nesuteikta. \\
\hline $\begin{array}{l}\text { Pigu. Dažnai internete kainos mažesnès, nei fizinėse } \\
\text { parduotuvėse. }\end{array}$ & Gauta netinkamos kokybės prekè ar paslauga. \\
\hline 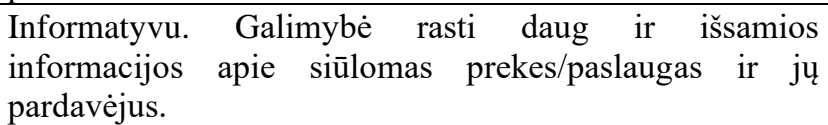 & $\begin{array}{l}\text { Produkto neišbandymas t. y. neturèjimas galimybės } \\
\text { apžiūrèti prekę. }\end{array}$ \\
\hline Asortimento apimtis - internete didesnè produktų pasiūla. & $\begin{array}{l}\text { Nepasitikèjimas ir nesaugumas. Baimé dèl apgaulingų } \\
\text { mokèjimų, aferų ir asmeninès informacijos vagystès } \\
\text { (ịsilaužèliai). }\end{array}$ \\
\hline $\begin{array}{l}\text { Papildoma pirkejo teisių apsauga (teisè per } 7 \text { darbo dienas } \\
\text { nenurodant priežasčių grąžinti nepatikusias prekes ar } \\
\text { atsisakyti paslaugų ir atgauti visus sumokètus pinigus). }\end{array}$ & Diskomfortas dèl grąžinimo. \\
\hline $\begin{array}{l}\text { Greitas produktų palyginimas su kitu pardavèjų } \\
\text { produktais. }\end{array}$ & Vèlavimas gauti produktą. \\
\hline
\end{tabular}

Šaltinis: sudarytas autorių pagal Hasan (2019), Jain (2020); Išoraité, Miniotienė (2018), Alamdari ir kt. (2020), 2021

Norint suprasti vartotojų elgseną internete, verta išsiaiškinti veiksnius, skatinančius pirkimą internete. Skirtingi autoriai išskiria skirtingus veiksnius. Autorès Andersone ir Gaile-Sarkane (2009) išskiria, socialinius ir asmeninius motyvus. Autorių teigimu socialiniai ir asmeniniai internetinio pirkimo veiksniai skiriasi nuo tradicinio - fizinio pirkimo. Autoriai Perea ir Monsuwé, Dellaert, Ruyter (2004) nurodo, kad požiūri ir ketinimą apsipirkti internete veikia ne tik naudojimo paprastumas, naudingumas ir malonumas, bet nekontroliuojami veiksniai, tokie kaip vartotojo bruožai, situaciniai veiksniai, produkto savybès, ankstesnè apsipirkimo internetu patirtis ir pasitikèjimas pirkti internetu. Baubonienė ir Gulevičiūtè (2015) išskiria šiuos veiksnius, darančius įtaką vartotojams apsipirkti internetu: klientų pasitenkinimas, logistiniai ir technologiniai veiksniai. Naudingiausias apsipirkimo internetu veiksnys buvo nustatytas kaip galimybė palyginti kainas ir pirkti už mažesnę kainą. Bucko 
(2018) teigia, kad pagrindiniai veiksniai, lemiantys pirkimą internetu yra vartotojų amžius bei naudojimosi internetu ịūdžiai. Nagrath, Gupta (2021) mano, kad vartotojų gyvenimo būdas ir ilgos darbo valandos apsipirkimą internetu daro patogiu ir taupančiu laiką, palyginti su tradiciniu apsipirkimu. Alam ir Elaasi (2016) atliktame tyrime nustatè, kad produkto kokybè yra pagrindinis veiksnys, kuris neramina vartotojus perkant internetu.

Autoriai Koch, Frommeyer ir Schewe (2000) teigia, kad pandemijos metu apsipirkimas internetu pradedamas analizuoti kaip išorinis naudingumo veiksnys t. y. sumažinantis vartotojų užsikrètimo riziką, užkrentant kelią kontaktui su kitais žmonėmis. Yan, Zheng, Siddik, Li Dong, ir Dou (2021) atliko tyrimo metu nustatė, kad pandemijos metu pastebèta didesnė išorinių veiksnių įtaka/spaudimas vartotojų elgesiui apsiperkant internetu t. y. žiniasklaidos, reklamos, TV bei socialinių tinklų. Karantino metu, sutrikus daugumos įmonių veiklai, užsidarius restoranams, barams, kino teatrams buvo apribota galimybė užsiimti ịprasta laisvalaikio veikla. İmonių darbuotojai susidūrè su naujais iššūkiais dirbdami visą dieną nuotoliniu būdu. Tokiu būdu vartotojai apsipirkimą pavertè pramoga.

Išanalizavus užsienio mokslininkų atliktų tyrimų duomenis, galima teigti, kad COVID-19 pandemija pakeitė vartotojų sprendimus ir apsipirkimą internetu elgesį bei dar labiau paryškino el. prekybos privalumus, pritraukdami ì ši kanalą vartotojus, kurie anksčiau prioritetą galbūt teikdavo pirkimui fizinèse parduotuvėse. Tikètina, kad nauji per pandemiją susiformavę vartotojų ịpročiai išliks ir ilgesnejje perspektyvoje bei lems dar didesnị el. prekybos sektoriaus augimą.

\section{Elektroninės prekybos Lietuvoje COVID-19 pandemijos laikotarpiu statistinių pokyčių analizè}

Norint išanalizuoti pirkimo internetu apimtis ir vartotojų elgseną, reikia apžvelgti elektroninès rinkos dalyvių statistinius (įmonių apyvartos, bankų, interneto naudotojų, tyrimo bendrovių) duomenis.

Elektroninė prekyba negalima be siuntų (kurjerių) tarnybų veiklos. Lietuvoje pagal užimamą rinkos dali didžiausios yra UAB „DPD Lietuva“, AB „Lietuvos paštas“ ir UAB „Venipak Lietuva“.

Siuntų tarnybos „Venipak“ rinkodaros vadovè Raudonienè teigia, kad paskelbus antraji karantiną, i̇monès privačių klientų srautas išaugo 45 proc. palyginti su 2019 m. Karantino metu keitèsi ir pirkinių krepšelis. $2020 \mathrm{~m}$. „Venipak” siuntų pristatymo paslaugomis naudojosi žaislais, elektronikos prekèmis bei buitine technika prekiaujančios įmonės, o $2021 \mathrm{~m}$. šalia šių kategorijų itin ženkliai augo kosmetikos, maisto prekių, namų apyvokos prekių pristatymas (OSP, 2020).

$\mathrm{AB}$ „Lietuvos paštas“ konsoliduoto metinio pranešimo duomenimis pašto paslaugu pardavimo pajamos išaugo 7,8 proc. nuo 69,3 mln. eurų $2019 \mathrm{~m}$. iki 74,7 mln. eurų $2020 \mathrm{~m}$. Pagal tarpinio pirmo pusmečio finansinių rezultatų pristatymo duomenis $2021 \mathrm{~m}$. pirmojo pusmečio pašto paslaugų pardavimo pajamos sudarė 41,4 mln. eurų ir palyginimui su $2020 \mathrm{~m}$. pirmu pusmečiu išaugo 23,3 proc. (33,6 mln. eurų) (https://www.post.lt/sites/default/files/Lietuvos\%20pa\%C5\%A1to\%20metinis\%20 prane\%C5\%A1imas\%202020.pdf, 2021).

AB „Lietuvos pašto“ siuntų savitarnos terminalais „LP Express“ persiųstų siuntų pirmajji 2021 m. pusmetị, palyginti su tuo pat laiku pernai, padaugejo apie 70 proc. iki 4,4 mln. vienetų, o pajamos iš šių paslaugų siekė $8,8 \mathrm{mln}$. eurų, t. y. 58 proc. daugiau. Norint įvykdyti visus užsakymus, reikia plèsti veiklą, todėl per $2021 \mathrm{~m}$. pirmą pusmetį buvo įrengta 15 naujų paštomatų (1997 naujos dèžutès). Šiuo metu yra 284 „LP Express“ paštomatai (41415 déžutès) 89-iose gyvenvietèse.

UAB „DPD Lietuva“" pajamos 2020-aisiais padidejo 33 proc. iki 45,840 mln. eurų, nurodoma Registrų centrui pateiktoje UAB „DPD Lietuvos“ finansineje ataskaitoje. Grynasis pelnas siekè 4,3 mln. eurų, o tai buvo 2,3 karto didesnis nei $2019 \mathrm{~m}$. (1,85 mln. eurų). Ši bendrovè per metus pristatė 9,9 mln. siuntų - 41,4 proc., arba 2,9 mln. daugiau nei užpernai (BNS, 2021). Praejjusiais metais UAB „DPD Lietuva“ teigia i plètrą investavusi $2,65 \mathrm{mln}$. eurų ir pastačiusi 60 naujų siuntų atsièmimo terminalų - jų skaičius metų pabaigoje siekè 145, o iki $2021 \mathrm{~m}$. vidurio turimą paštomatų tinklą planavo išplèsti iki 235 paštomato (DPD, 2020).

Didžiausią paštomatų tinklą Lietuvoje valdanti bendrovè UAB „Omniva LT“ 2020 metais sparčiai didino veiklos apimtį ir fiksavo rekordinius veiklos rezultatus. UAB „Omniva LT“ pranešime (2021) teigiama, kad siekdama patenkinti išaugusi siuntų pristatymo poreiki bendrovè daugiau nei du kartus padidino savo darbuotojų skaičių ir investavo daugiau nei $1 \mathrm{mln}$. eurų ị infrastruktūros plètrą. 
Todèl bendrovè pasiekė 103 proc. didesnę (18,32 mln. eurų) apyvartą nei $2019 \mathrm{~m}$. (9,03 mln. eurų), o pelną padidino 5 kartus - iki $1,8 \mathrm{mln}$. eurų. Per Lietuvoje veikianti 300 paštomatų tinklą UAB „Omniva LT“ $2020 \mathrm{~m}$. vartotojams pristate daugiau nei $8 \mathrm{mln}$. siuntų - beveik 150 proc. daugiau nei 2019 m. Vidutinis bendrovès darbuotojų skaičius išaugo nuo 145 iki 300, o jų atlygio fondas - 127 proc. ir siekè $6,5 \mathrm{mln}$. euru.

2021 m. UAB „Omniva LT“ atidare išorinę prekių grąžinimo platformą FLIPO, per kurią galima grąžinti prekes pirktas ir fizinèse parduotuvèse. UAB „Omniva LT“ generalinis direktorius Simonas Bielskis sako, kad didejjantị e. komercijos mastą atspindi smarkiai išaugusi prekių pristatymo ir grąžinimo paslaugų paklausa. Pirmą šių metų pusmetį bendrovė Lietuvoje pristatė daugiau nei $6 \mathrm{mln}$. siuntų - beveik 70 proc. daugiau nei tuo pačiu laikotarpiu $2020 \mathrm{~m}$. Tai daugiau kaip 60 proc. - nuo 8 iki $13 \mathrm{mln}$. eurų - išaugino ịmonès pajamas, taip pat daugiau nei 2,5 karto padidino pelną - jis per pirmą pusmeti pasiekè beveik $3 \mathrm{mln}$. euru. Antroje metu pusèje ịvairiose Lietuvos vietose bus ịrengta 50 naujų paštomatų, o investicijos i šią plètrą sieks $1,5 \mathrm{mln}$. eurų. Igyvendinus ši projektą vartotojai visoje šalyje galès naudotis 350 bendrovės paštomatų su daugiau kaip 47 tūkst. siuntų skyrelių (BNS, 2021).

Apžvelgus pagrindinių Lietuvoje veikiančių siuntų (kurjerių) tarnybų statistinius duomenis, šių duomenų patvirtinimą galime rasti ir Lietuvos Statistikos departamento pateikiamoje informacijoje. Oficialios statistikos portalo duomenimis (2 lentelè) kurjerių pajamos $2020 \mathrm{~m}$. antrą ketvirtị, tuo metu, kai buvo paskelbtas karantinas, kilo 14 procentinių punktų palyginus su $2019 \mathrm{~m}$. antru ketvirčiu, atšaukus karantiną, trečią ketvirtị krito 2,3 procentiniais punktais palyginus su 2019 m., tačiau tai buvo 2 proc. daugiau nei antrą ketvirtị. $2020 \mathrm{~m}$. ketvirtą ketvirtị kurjerių pajamos išaugo 6,7 procentiniais punktais nei $2019 \mathrm{~m}$. Tačiau didžiausias kurjerių pardavimų pajamų šuolis ịvyko $2021 \mathrm{~m}$. pirmą ketvirtị, kai pajamos pakilo 43,6 procentais palyginus su $2020 \mathrm{~m}$. pirmu ketvirčiu. Antrą ketvirtị, atpalaidavus karantino suvaržymus, pardavimo pajamos krito, tačiau jos buvo 16 proc. didesnès palyginus su 2020 m. antru ketvirčiu, kai buvo ịvestas pirmasis karantinas.

2 lentelè. Paslaugu imoniu pardavimo pajamos (be PVM) tūkst. EUR

\begin{tabular}{|l|c|c|c|c|c|c|c|c|c|}
\hline & $2019 \mathrm{~K} 2$ & $2019 \mathrm{~K} 3$ & $2019 \mathrm{~K} 4$ & $2020 \mathrm{~K} 1$ & $2020 \mathrm{~K} 2$ & $2020 \mathrm{~K} 3$ & $2020 \mathrm{~K} 4$ & $2021 \mathrm{~K} 1$ & $2021 \mathrm{~K} 2$ \\
\hline $\begin{array}{l}\text { Pašto ir pasiuntiniu } \\
\text { (kurjerių) veikla }\end{array}$ & 39819,9 & 47467,1 & 55349,1 & 39325,4 & 45437,9 & 46389,2 & 59051,7 & 56459,1 & 52672,5 \\
\hline \multicolumn{8}{|c|}{ Šaltinis: https://osp.stat.gov.lt/statistiniu-rodikliu-analize?indicator=S8R755\#/ }
\end{tabular}

Statistikos departamento pateikti duomenys patvirtina didžiųjų siuntų tarnybų pateiktas ataskaitas apie kilusias pajamas 2020 ir 2021 metais.

Lietuvoje vartotojų apklausas dėl internetinès prekybos atliko keletas imonių. „Swedbank“ $2021 \mathrm{~m}$. atlikto tyrimo duomenimis el. prekybos apimtys toliau išlaiko spartu augimą, tačiau tai ne vienintelis stebimas vartotojų elgsenos pokytis: per pastaruosius kelerius metus susiformavo reguliarių interneto pirkèjų grupé; gyventojai kur kas dažniau internetu perka maisto produktus ir prioritetą teikia naujam prekių pristatymo būdui. „Swedbank“ duomenys (2021) rodo, kad per pirmajj 2021 metų pusmeti banko klientai lietuviškose el. parduotuvėse išleido ne mažiau $754 \mathrm{mln}$. eurų. Palyginus su atitinkamu laikotarpiu praejjusiais metais, ši suma išaugo 55 proc. Pasikeite ir kiti šalies gyventojų apsipirkimo ịpročiai, ị kuriuos tampa vis svarbiau atsižvelgti interneto prekybininkams ir kitiems paslaugų internetu teikèjams. Kaip rodo apklausos rezultatai, internetu kas savaitę ir dažniau apsiperka beveik 50 proc. šalies gyventojų. Kas septintam (15 proc.) tai yra tapę praktiškai kasdieniu ịpročiu, tai yra, internetu apsiperkama po kelis kartus per savaitę ar kiekvieną dieną. Remiantis apklausa, didžioji dalis šalies gyventojų jau yra pabandę ịsigyti prekių internetu - tokių respondentų dalis $18-56 \mathrm{~m}$. amžiaus grupèje sudaro daugiau kaip 90 proc. Reguliariai internetu dažniausiai apsiperka $26-45 \mathrm{~m}$. amžiaus respondentai bei didžiųjų miestų gyventojai.

Per pandemiją pasikeitusius vartotojų apsipirkimo įpročius ir su tuo susijusius rekordus fiksuoja ir prekybos centrai - platformos internete.

Didžiausio Lietuvoje internetinès prekybos centro UAB „Pigu.lt“ užsakymu bendrovès „Norstat“ atlikta apklausa rodo, kad 2020 metais kalėdines dovanas internetu ịsigijo beveik trečdalis lietuvių (29 proc.), tarp perkančių dovanas internetu 17 proc. yra 60-74 metų pirkèjai, 24 proc. apklaustųu nurodé, kad internetu dovanas perka kasmet. 5 proc. apklaustujų tai bus pirmieji metai, kai dèl 
pandemijos visas kalėdines dovanas jie pirko neišèję iš namų. UAB „Pigu.lt“ prekybos centro internete rinkodaros vadovas Kačerauskas (2021) teigia, kad galima tvirtai kalbėti ne apie laikina e-komercijos bumą, o stabilų augimą, mat pardavimus e. prekyboje generavo ne tik naujų pirkèjų apsisprendimas išmėginti apsipirkimą internete, bet didžiausia dalimi lojalūs klientai, kurie saugų ir patogų apsipirkimą internete ịtraukè ị savo kasdienę rutiną. 2020 metais UAB „Pigu.lt“ prekybos centre internete fiksuotas didesnis nei 30 proc. pardavimu augimas palyginus su $2019 \mathrm{~m}$. Pasak rinkodaros vadovo, pirmo karantino piko metu UAB „Pigu.lt“ stebejo ir 80 proc. didesnius pardavimus nei tuo pačiu laikotarpiu 2019 metais, tačiau ir antrasis karantinas parodè, kad poreikis el. prekybai yra stabilus.

UAB „Varle.1t“ pardavimai $2020 \mathrm{~m}$. išaugo 48 proc. iki 40,73 mln. euru ( $2019 \mathrm{~m}$. - 27,58 mln. eurų). Grynasis pelnas per metus šoktelèjo 6 kartus, iki 957419 eurų. UAB „Varle.lt" ịkūrèjas ir vadovas M. Butauskas duodamas interviu „Verslo žinioms“ pabrěžia, kad $40 \mathrm{mln}$. eurų siekianti UAB „Varle“ apyvarta - tik grupès pardavimai Vilniuje. Visi užsakymai, kurie iškeliauja ị Kauną, Klaipėdą ar kitus miestus čia neatsispindi. Skirtinguose miestuose UAB „Varle.lt“ dirba su franšizès partneriais, tad jei skaičiuotų visus pardavimus, kaip grupès, tai per praejjusius metus jie siekè apie $70 \mathrm{mln}$. eurų. UAB „Varle.1t“ turi franšizès sutartis 18-oje miestų. Didžiausias apyvartos augimas net 83 proc. buvo pirmojo karantino metu, $2020 \mathrm{~m}$. antrą ketvirtic. İmonė pati praplètė prekių krepšelį: vaikų prekių, papildų, tekstilès gaminių, baldų, avalynès, kosmetikos asortimentas, buvo pradèta prekiauti loterijos bilietais, o karantino pabaigoje - ir maisto produktais. Karantino metu pradejo kviesti įvairias įmones prekiauti platformoje. M. Butauskas teigia, kad per metus platformos apyvarta išaugo beveik 10 kartų, o i̇monių, nusprendusių imtis prekybos čia, skaičius padidèjo 5 kartus. „Varle.lt“ skaičiuoja, kad apie 13 proc. apyvartos tenka išorès įmonèms (Budreikienè, Balčiūnienė, 2021).

Kiekvieną mènesi yra sudaromas naujausias interneto parduotuvių reitingas, remiantis internetinių parduotuvių pateiktais ar viešai prieinamais lankytojų srauto duomenimis. Reitingas skelbiamas InternetoParduotuves.lt svetainèje. Reitinge dalyvavo 157 elektroninès parduotuvès, kurių populiariausios pateiktos 2 paveiksle.

Šio puslapio duomenimis tiek $2020 \mathrm{~m}$., tiek $2021 \mathrm{~m}$. interneto vartotojų nuomone populiariausios el. parduotuvės beveik nesikeičia. Tai pigu.lt, senukai.lt, tele2.lt ir varle.lt. Aukščiau aptarti pigu.lt ir varle.lt finansiniai duomenys rodo, kad tai gerai žinomi ir dažniausiai lankomi el. prekybos centrai, prekiaujantys labai įvairaus asortimento prekèmis, todèl pirkejjų srautai generuoja apyvartą.

$2020 \mathrm{~m}$. Gemius atlikto tyrimo metu nustatyta, kad lietuviams populiariausios užsienio el. parduotuvės yra aliexpress.com, amazon.com, ebay.com, wish.com ir asos.com. Tačiau jos nesudaro didelès konkurencijos Lietuvoje registruotoms įmonėms.

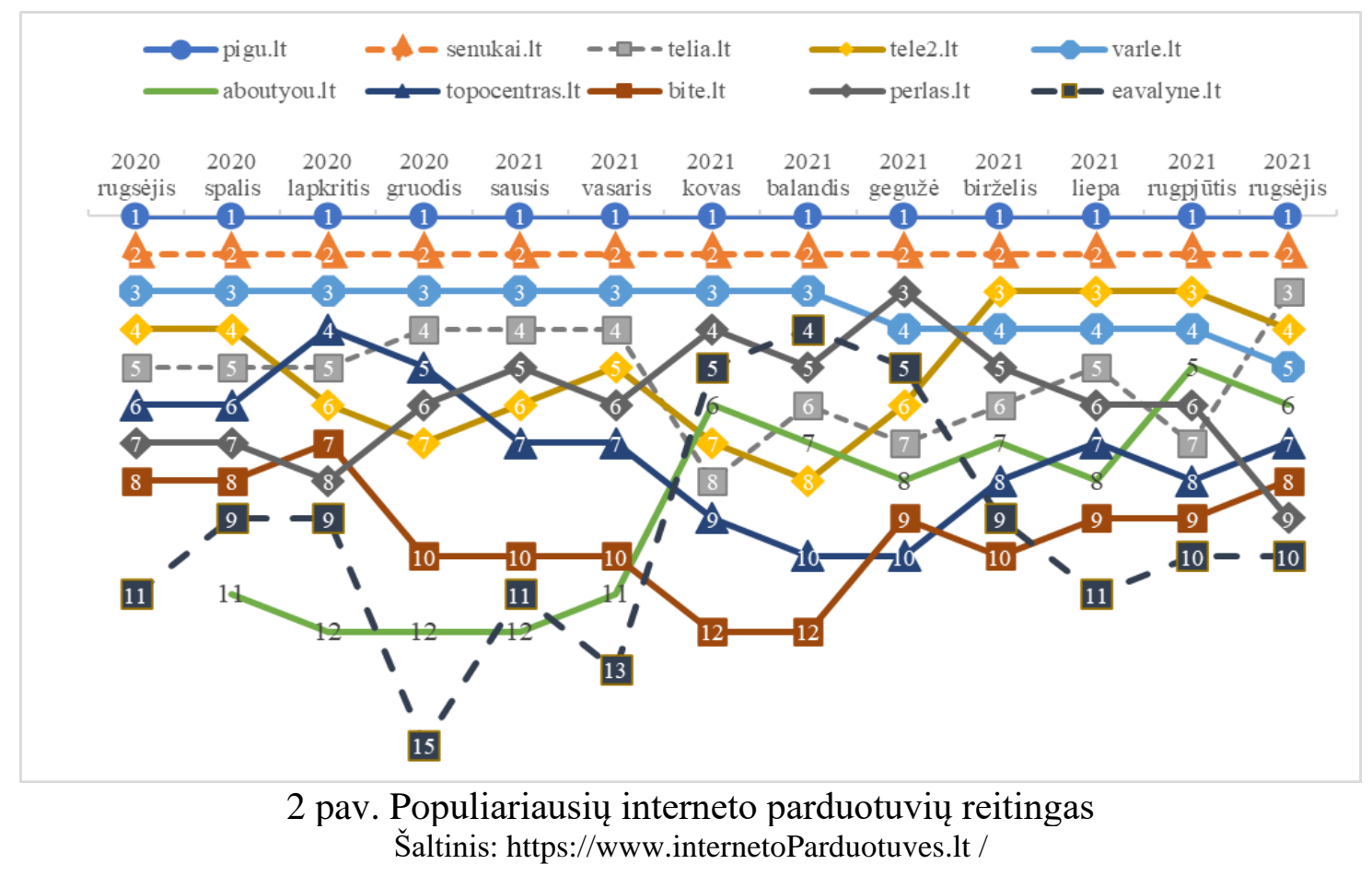


Išanalizavus verslo įmonių, susijusių su elektronine prekyba, finansinius ir kitus statistinius duomenis, galima teigti, kad COVID-19 pandemija ir karantinas turëjo itakos apyvartos ir pelno augimui, o ypač tai akivaizdu $2021 \mathrm{~m}$. pirmajame ketvirtyje. Statistiniai duomenys rodo, kad jau trečias karantino mėnuo pakeitė žmonių apsipirkimo ipročius. Atpalaidavus karantino suvaržymus elektroninių pardavimų pajamos krito, tačiau jos vis tiek išliko didesnès nei priešpandeminị laikotarpị. Visgi, ekspertai tikina, kad pasibaigus karantinui žmonès ir toliau aktyviai pirks internetu. Šioks toks sumažejimas yra prognozuojamas, tačiau apskaitai - skaičiai bus pakilę, kadangi šis ịprotis liks ypač tiems, kurie dar iki šiol niekada nepirko internetu ir pamate tokios prekybos privalumus.

\section{Elektroninès prekybos vartotojų pokyčiai pandemijos laikotarpiu}

Pagal Statistikos departamento duomenis skaitmeninių technologijų naudojimas namų ūkiuose pastaraisiais metais sparčiai išaugo, o ypač - vyresnès kartos (Oficialiosios statistikos portalas, 2021). Kiekvienais metais kyla skaičius asmenų, kurie naudojasi internetu. 2019 m. naudojosi 81,6 proc. visų 16-74 m. amžiaus asmenų, $2021 \mathrm{~m}$. - 86,9 proc. Iš karto po pirmosios pandemijos bangos atliktas tyrimas parodè, kad šoktelèjo internetą atradusių vyresnio amžiaus (65-74 metų) žmonių skaičius. Palyginti su 2019 metais, šioje amžiaus grupejje interneto vartojimas išaugo 5,5 procentais - iki 46 proc. 2020 metais. 2021 metais internetu naudojosi jau 55,2 proc. 33 proc. šio amžiaus asmenų internetu èmè naudotis kasdien.

Vyresnio amžiaus asmenys (65-74 m.) internetą dažniausiai naudojo ieškant naujienų, laikraščių, žurnalų skaitymui (41,2 proc.), ryšiams (37,5 proc.) bei informacijos apie prekes ir paslaugas paieškai (33,5 proc.). Tos pačios veiklos yra populiariausios ir 55-64 m. amžiaus grupejje (atitinkamai 63,6, 62,2 ir 58,4 proc.). Taigi viena populiariausių veiklų internete ir vyresnio amžiaus asmenų tarpe yra informacijos apie prekes ar paslaugas paieška (Oficialiosios statistikos portalas: Asmenys, kurie naudojosi internetu asmeniniais tikslais, 2021).

Nuo 2020 metų, kai buvo paskelbtas pirmasis karantinas, asmenų, pirkusių ar užsisakiusių prekes ar paslaugas internetu, skaičius šoktelèjo 6,2 proc. iki 60,0 proc., kai ankstesniais metais šis rodiklis tolydžiai augo, maždaug po 5 proc. per metus (žr. 3 lentelę).

3 lentelè. Asmenys, pirkę ar užsakę prekių ar paslaugų internetu proc., nuo visų asmenų atitinkamoje amžiaus grupejje

\begin{tabular}{|c|c|c|c|c|c|c|c|}
\hline & $\mathbf{2 0 1 6}$ & $\mathbf{2 0 1 7}$ & $\mathbf{2 0 1 8}$ & $\mathbf{2 0 1 9}$ & $\mathbf{2 0 2 0}$ & $\mathbf{2 0 2 1}$ \\
\hline $\begin{array}{c}\text { per } \\
\text { paskutinius } \\
\text { metus }\end{array}$ & $\begin{array}{c}\text { Visi 16-74 metu amžiaus } \\
\text { asmenys }\end{array}$ & 33,4 & 38,1 & 43,4 & 48,4 & \multirow{2}{*}{53,8} & 60,0 \\
\cline { 2 - 8 } & $16-24$ & 52,1 & 57,6 & 62,7 & 68,1 & 72,2 & 84,0 \\
\cline { 2 - 8 } & $16-29$ & 55,8 & 61,1 & 67,3 & 72,6 & 78,1 & 86,9 \\
\cline { 2 - 8 } & $25-34$ & 59,4 & 66 & 71,4 & 79,1 & 86,2 & 90,8 \\
\cline { 2 - 8 } & $35-44$ & 44,2 & 51,8 & 60 & 65,6 & 77 & 81,9 \\
\cline { 2 - 8 } & $45-54$ & 24,2 & 30,1 & 35,8 & 41,9 & 48,7 & 54,6 \\
\cline { 2 - 8 } & $55-64$ & 13,2 & 17 & 21,5 & 25,7 & 27,7 & 34,1 \\
\cline { 2 - 9 } & $65-74$ & 4,3 & 4,4 & 8,4 & 10,1 & 12,4 & 16,8 \\
\hline
\end{tabular}

Šaltinis: https://osp.stat.gov.lt/statistiniu-rodikliu-analize\#/

Palyginus $2021 \mathrm{~m}$. duomenis su priešpandeminiu laikotarpiu (2019 m. duomenimis), dažniausiai internetu pirko 25-34 m. amžiaus asmenys (90,8 proc.) ir tai yra 11,7 proc. daugiau nei $2019 \mathrm{~m}$. Ypač išaugo pirkèjų (16,3 proc.) 35-44 m. amžiaus grupejje ir tai sudaro 81,9 proc. nuo visų to amžiaus grupès asmenų. Suaktyvejjo jaunimo 16-24 m. amžiaus grupejje el. pirkimo veikla. 84 proc. šio amžiaus grupès asmenų yra $2021 \mathrm{~m}$. pirkusių ar užsisakiusių prekes ar paslaugas internetu per paskutinius metus ir t. y. apie 16 proc. daugiau nei 2019 m. 16-29 m. amžiaus grupès aktyvumas kilo 14,3 proc. palyginus su $2019 \mathrm{~m}$. ir sudaro 86,9 proc. visų tos grupès asmenų skaičiaus.

Tarp 45-54 metų lietuvių internetu prekes ar paslaugas $2021 \mathrm{~m}$. bent kartą užsakinèjo 54,6 proc. apklaustų gyventojų, 2019 m. tokių buvo 41,9 proc., t. y. beveik 12,7 proc. daugiau nei prieš pandemiją. 
Pagal oficialiosios statistikos portalo duomenis - vyriausioje grupejje (65-74 m.), neiškeldami kojos iš namų, apsipirkinejjo jau kas šeštas gyventojas arba 16,8 proc. šios amžiaus grupès interneto vartotojų. 2019 metais jų procentas siekè 10,1 proc.

Oficialiosios statistikos portalas duomenimis karantinas apsipirkimui internetu $2020 \mathrm{~m}$. mažiausiai įtakos turèjo asmenims amžiaus grupèje 55-64 m. (apie 2 proc.). Tačiau užsitęsus suvaržymams $2021 \mathrm{~m}$. jau 34,1 proc. šio amžiaus asmenų buvo išbandę pirkimą internetu, o t. y. 8,4 proc. daugiau nei prieš pandemiją.

2020 m. liepą tyrimų bendrove „Gemius“ pristatė e-komercijos tyrimą, kuriame atskleidžiami žmonių ịpročiai perkant internetu. Pasirodo, jog geresnès kainos internete, lyginant su kainomis tradicinėse parduotuvėse, yra pagrindinis, internetu pirkti motyvuojantis, faktorius. Sprendimą pirkti internetu skatina ir nuolaidos bei specialūs pasiūlymai, pristatymas ị namus. 52 proc. apklaustų lietuvių $2020 \mathrm{~m}$. karantino metu pirko internetu, 26 proc. teigé, kad nepirko, bet planuoja pirkti artimoje ateityje (https://www.gemius.lt/e-komercijos-naujienos/e-komercijos-tyrimas-lietuvoje-irlatvijoje-kas-motyvuoja-pirkti-internetu-ir-kas-keitesi-karantino-metu.html, 2020).

$2021 \mathrm{~m}$. pradžioje tyrimų bendrovès „Gemius“ atlikta Lietuvos interneto vartotojų apklausa parodè, kad 83 proc. internetu besinaudojančių lietuvių $2020 \mathrm{~m}$. pirko internetu - trečdalis tai darè kelis kartus per mėnesį. Daugiau nei pusè, 56 proc., gyventojų teigè, kad pirkti internetu juos paskatino pandemija. Be to, du penktadaliai respondentų pripažino, kad jų išlaidos perkant internetu per karantiną išaugo. 27 proc. gyventojų mano, kad $2021 \mathrm{~m}$. internetu pirks dar daugiau. $2019 \mathrm{~m}$. taip manančių buvo tik 22 proc. (Omniva LT, 2021).

Statistikos departamento duomenimis iš 2021 metais pirkusių ar užsisakiusių fizinių prekių asmenų 91,7 proc. tai atliko iš Lietuvoje esančių el. parduotuvių, 36,4 proc. iš el. parduotuvių registruotų ES, 29,5 proc. iš kitos pasaulio šalies (Oficialiosios statistikos portalas: Asmenys, pirkę ar užsakę fizinių prekių, 2021).

Atlikus elektroninès prekybos vartotojų analizę COVID-19 pandemijos laikotarpiu galima teigti, kad skaitmeninių technologijų naudojimas namų ūkiuose pastaraisiais metais sparčiai išaugo, o ypač vyresnès kartos. Nuo 2020 metų, kai buvo paskelbtas pirmasis karantinas, asmenų, pirkusių ar užsisakiusių prekes ar paslaugas internetu, skaičius šoktelejjo nuo 6,2 proc. iki 60,0 proc., Dauguma elektroninès prekybos vartotojų teigia, kad pirkti internetu juos paskatino pandemija. Žmonès, kurie pabando el. prekybą, beveik visada yra linkę sugrịžti. Manoma, kad net ir pasibaigus karantinui didelè dalis šių pirkèjų ir toliau rinksis taupyti savo laiką bei pinigus ir užsisakys prekes internete ar tiesiog mobiliojoje aplikacijoje.

\section{Išvados}

1. Pagrindiniai veiksniai, lemiantys pirkimą internetu yra vartotojų amžius, naudojimosi internetu igūdžiai, patogumas, patikimumas, malonumas ir kt. nekontroliuojami veiksniai. Užsienio mokslininkų atlikti tyrimai parodè, kad COVID-19 pandemija pakeitè vartotojų sprendimus ir apsipirkimą internetu elgesi.

2. Išanalizavus verslo įmonių, susijusių su elektronine prekyba, finansinius ir kitus statistinius duomenis, galima teigti, kad COVID-19 pandemija ir karantinas turejo itakos apyvartos ir pelno augimui, o ypač tai akivaizdu $2021 \mathrm{~m}$. pirmajame ketvirtyje. Atpalaidavus karantino suvaržymus elektroninių pardavimų pajamos krito, tačiau jos vis tiek išliko didesnès nei priešpandeminị laikotarpị.

3. Išanalizavus Statistikos departamento, tyrimų bendrovès „Gemius“, elektroninès prekybos dalyvių duomenis, galima teigti, kad Lietuvos gyventojų apsisprendimui pirkti internetu COVID-19 pandemija ir karantinas turèjo didelę itaką, o ypač tai parodo $2021 \mathrm{~m}$. asmenų apklausų, elektroninès prekybos įmonių finansiniai duomenys.

\section{Literatūra}

1. Alam, M.Z., Elaasi, S. (2016). A study on consumer perception towards e-shopping in KSA. International Journal of Business and Management. 11 (7), 202. doi:10.5539/ijbm.v11n7p202 
2. Alamdari, P.M., Navimipour, N.J., Hosseinzadeh, M., Safaei, A.A., Darwes, A. (2020). A Systematic Study on the Recommender Systems in the E-Commerce. IEEE Access, 8, 115694115716. doi: 10.1109/ACCESS.2020.3002803

3. Andersone, I., Gaile-Sarkane, E. (2009). Behavioral differences in consumer purchasing behavior between online and traditional shopping: case of Latvia, Ekonomika ir vadyba 14. 345-352.

4. Baltijos šalių pirkèjų ịpročiai: kas apsipirks saugiausiai, o kas - išleis daugiausiai? (2020, lapkričio 28) Prieiga per internetą: https://www.delfi.lt/verslas/verslas/baltijos-saliu-pirkeju-iprociai-kasapsipirks-saugiausiai-o-kas-isleis-daugiausiai.d?id=85855265

5. Baubonienè, Ž., Gulevičiūtè. G. (2015). Factors Influencing Consumers Online Shopping Decision: Present and Future Evidence from Lithuania. Social Technologies 5 (1). doi:10.13165/ST-15-5-1-06

6. BNS. „DPD Lietuva“ ketina per dvejus metus padidinti pajamas iki $50 \mathrm{mln}$. eurų. (2021, gegužès 3). Prieiga per internetą: https://www.delfi.lt/verslas/verslas/dpd-lietuva-ketina-per-dvejus-metuspadidinti-pajamas-iki-50-mln-euru.d?id=87089493

7. Bucko,. Kakalejčik, L., Ferencova M., (2018) Online shopping: factors that affect consumer purchasing behaviour. Cogent Business \& Management. 5 https://doi.org/10.1080/23311975.2018.1535751

8. Budreikienė, J., Balčiūnienė, R. (2021). E. prekybininkès „Varle.lt“ pelnas pandemijos metais išaugo 6 kartus. Verslo žinios. Prieiga per internetą: https://www.vz.lt/prekyba/2021/06/03/eprekybininkes-varlelt-pelnas-pandemijos-metais-isaugo-6-kartus

9. Daroch, B., Nagrath, G., Gupta, A. (2021). A study on factors limiting online shopping behaviour of consumers. Rajagiri Management Journal. 15 (1), 39-52. https://doi.org/10.1108/RAMJ-072020-0038

10. Davidavičienè, V., Gatautis, R., Paliulis, N., Petrauskas, R. (2009). Elektroninis verslas: vadovèlis. Vilnius: Technika.

11. DPD. DPD Baltijos šalyse paštomatų tinklą plès daugiau nei 2 kartus: sparčiausia plètra numatyta Lietuvoje. (2020, liepos 1). Pranešimas spaudai. Prieiga per internetą: https://www.dpd.com/lt/ 1t/2020/07/01/dpd-baltijos-salyse-pastomatu-tinkla-ples-daugiau-nei-2-kartus/

12. E-komercijos tyrimas Lietuvoje ir Latvijoje: Kas motyvuoja pirkti internetu ir kas keitesi karantino metu? (2020, liepos 7). Prieiga per internetą: https://www.gemius.lt/e-komercijos-naujienos/ekomercijos-tyrimas-lietuvoje-ir-latvijoje-kas-motyvuoja-pirkti-internetu-ir-kas-keitesi-karantinometu.html

13. Hasan, S. M. (2019). Advantages and disadvantages of e-Commerce. Prieiga per internetą: http://www.itseba.com/advantages-and-disadvantages-e-commerce

14. Yan, C., Zheng, G., Siddik, A.B., Li Dong, Q., and Dou, Ch. (2021). Factors Affecting the Consumers Online Shopping During the COVID-19 Pandemic in China. Revista Argentina de Clínica Psicológica 2021, XXX (1), 853-864. doi:10.24205/03276716.2020.2081

15. Išoraite, M., Miniotienè, N. (2018). Electronic Commerce: Theory and Practice. Integrated Journal of Business and Economics. 2 (2), 194-200. Prieiga per internetą: https://mpra.ub.unimuenchen.de/91034/1/MPRA_paper_91034.pdf

16. Jain, A. S. (2020). Top 10 benefits of online shopping that make your life easy. Prieiga per internetą: https://toughnickel.com/frugal-living/Online-shopping-sites-benefits

17. Katawetawaraks, Ch. and Wang, Ch., (2013). Online Shopper Behavior: Influences of Online Shopping Decision. Asian Journal of Business Research, 1 (2). Prieiga per internetą: https://ssrn.com/abstract=2345198.

18. Koch, J., Frommeyer, B., and Schewe G. (2000). Online Shopping Motives during the COVID-19 Pandemic Lessons from the Crisis. Sustainability, 12 (24). https://doi.org/10.3390/su122410247.

19. Kodèl daugiau perkame internetu: kaip per metus pasikeite šalies gyventojų kasdienybè. Verslo žinios. (2021, vasario 25). Prieiga per internetą: https://www.vz.lt/reshapebusiness/2021/02/25/kodel-daugiau-perkame-internetu-kaip-per-metus-pasikeite-salies-gyventojukasdienybe

20. Oficialiosios statistikos portalas. (2021). Prieiga per internetą: https://osp.stat.gov.lt/statistiniurodikliu-analize\#/ 
21. Lietuvos paštas. (2021). Konsoliduotas metinis pranešimas 2020. Prieiga per internetą: https://www.post.lt/sites/default/files/Lietuvos \%20pa\%C5\%A1 to\%20metinis\%20prane\%C5\%A1i mas\%202020.pdf

22. Lietuvos paštas. (2021). Tarpinis 1 pusmečio finansinių rezultatų pristatymas. Prieiga per internetą: https://www.post.lt/sites/default/files/2021\%2008\%2031\%20Lietuvos\%20pa\%C5\%A1to\%20tarpin is\%20prane\%C5\%A1imas.pdf

23. Menasce, D., Almeida, V. (2000). Scaling for E-business: Technologies, Models, Performance, and Capacity Planning. New Jersey, Prentice-Hall, INC.

24. Niranjanamurthy, M., Kavyashree, K., Jagannath, S., Chahar, D. (2013). Analysis of E-Commerce and M-Commerce: Advantages, Limitations and Security issues. International Journal of Advanced Research in Computer and Communication Engineering 2 (6). Preiga per internetą: https://d1wqtxts1xzle7.cloudfront.net/49518931/7-Niranjanamurthy-Analysis_of_E-Commerce_ and_M-Commerce_Advantages-with-cover-page-v2.pdf?Expires $=1633901173 \&$ Signature $=$ BAhc FZWmoY8Zdi1 ony 1211iEW fMf2eeDs6OZCP9SzCE9ij-W amLnjwWNTqVmYZkPNOcwv8z WUZ9-UlF52-CiG4GAzL5gslTVDKfa2EYfdLWJ6xAfcT25gw7ulAePBPCfbRowXEIgqm PH4RHOzj7I5yIuW2R0r7Q93Y0BYAqUJfPb273ae2JDfNTb7tTH3OePnzJkswh7WzZWo48szBy G3bC93QRJr8kHnM6WbEGsGRowjpERPZ YnU2IiGvtzvJ3fDpH0jrBsNPjv3pkIUoJRosbzKwB tWEssL-yjKei4AAWhLwN1vHCr7YVxcAtNWdC89Z-rM0BFgSesX7sx4Sw_\&Key-PairId=APKAJLOHF5GGSLRBV4ZA

25. OECD (2013). Electronic and Mobile Commerce. OECD Digital Economy Papers, 228, OECD Publishing, Paris. http://dx.doi.org/10.1787/5k437p2gxw6g-en

26. Omniva LT. „Omniva LT“ pajamos pernai augo dvigubai, siuntų skaičius -8 milijonai. Pranešimas spaudai. (2021, balandžio 3). Prieiga per internetą: https://www.omniva.1t/index.php?article_id= 702\&article_token $=$ news \&page $=1118 \&$ action $=$ article $\&$

27. Omniva LT. „Omniva LT“ prognozès 2021-iesiems tvirtinasi - e. prekyba auga ir toliau. (2021, liepos 15). Prieiga per internetą: https://www.bns.lt/ee/topic/938/news/64248759/

28. OSP. COVID-19 keičia lietuvius: kalėdinių dovanų dairosi internete. (2020, gruodžio 11). Prieiga per internetą: https://osp.stat.gov.lt/covid-19-keicia-lietuvius-kalediniu-dovanu-dairosi-internete

29. Paliulis, N.K., Sabaityte, J. (2011). E. verslo modelių panaudojimas verslo plètrai. Contemporary issues in business, management and education '2011. doi: 10.3846/cibme.2011.18

30. Perea y Monsuwé, T., Dellaert, B.G.C., de Ruyter, K. (2004), What drives consumers to shop online? A literature review. International Journal of Service Industry Management, 15 (1), 102121. https://doi.org/10.1108/09564230410523358

31. Prashar, S., Sai Vijay T., Parsad, C. (2016). Segmenting online shoppers: A study of consumers' web portal selection motivations for e-shopping. Asian Academy of Management Journal , 21 (1), 27-46. Prieiga per internetą: https://smartlib.umri.ac.id/assets/uploads/files/0dfddaamj21012016_2.pdf

32. Puspitasari, N. B., S. W. Pramono, D. I. Rinawati, and F. Fidiyanti. (2020). Online consumer segmentation study based on factors affecting e-commerce selection. IOP Conference Series: Materials Science and Engineering. doi: 10.1088/1757-899X/722/1/012036

33. Ramayah, T., S. A. Rahman, N. C. Ling. (2018). How do Consumption Values Influence Online Purchase Intention among School Leavers in Malaysia? Revista Brasileira de Gestão de Negócios, 20 (4), 638-654. doi: 10.7819/rbgn.v0i0.3139

34. Swedbank. (2021). Internetu kas savaitę apsiperka beveik 50 proc. šalies gyventojų. Prieiga per internetą: https://blog.swedbank.lt/verslas-pranesimai-spaudai/internetu-kas-savaite-apsiperkabeveik-50-proc-salies-gyventoju

35. Varle.lt. „Varlè.lt“ pusmečio rezultatai viršijo lūkesčius: užsakymų padvigubejjo, apyvarta išaugo trečdaliu. (2020, liepos 27). Prieiga per internetą: https://www.delfi.lt/m360/tyrimai/varleltpusmecio-rezultatai-virsijo-lukescius-uzsakymu-padvigubejo-apyvarta-isaugotrecdaliu.d $\mathrm{id}=84861833$ 


\title{
STATISTICAL ANALYSIS OF CHANGES IN ELECTRONIC COMMERCE AND CONSUMER BEHAVIOR DURING THE COVID-19 PANDEMIC IN LITHUANIA
}

\author{
Jolanta Baronaitė, Eglè Gotautienè \\ Klaipeda University of Applied Sciences
}

\begin{abstract}
Summary
The global COVID-19 pandemic and quarantine measures have significantly changed consumer behaviour when purchasing goods and services online. The e-commerce sector, which has grown significantly in recent years, has made an even bigger breakthrough. During the quarantine period, businesses had to reorient to the changed consumer behaviour, thus dozens of new online stores appeared in the e-commerce market in Lithuania, and the incumbents recorded several times higher sales (revenue) growth rates. The article analyzes the trends of online shopping, the behaviour of consumers online shopping and the statistical analysis of online shopping during the COVID-19 quarantine period, based on scientific literature sources and statistical data analysis.
\end{abstract}

The object of the research - changes in e-commerce and consumer behavior during the COVID-19 pandemic. pandemic.

The aim of the study is to analyze the changes in e-commerce and consumer online shopping during the COVID-19

Research tasks:

1. To present the trends of e-commerce and the behavior of consumers buying online in a theoretical aspect.

2. To analyze statistical changes in e-commerce during the COVID-19 pandemic in Lithuania.

3. To analyze the behaviour of e-commerce consumers during the COVID-19 pandemic.

Research methods: analysis of scientific literature, data analysis method - descriptive statistics.

Were are analyzed the activity data of the largest parcel (courier) services LTD "DPD Lietuva", JSC "Lietuvos pastas", LTD "Venipak Lietuva" and LTD "Omniva LT".

It has been established that in 2020 the income of these companies rose from 7.8 percent AB "Lietuvos Paštas" up to 103 percent of LTD "Omniva LT". In the first half of the 2021, courier services felt the rise of e-commerce, the number of parcels increased by 50-70 percent. compared to in the first half of 2020. According to the data of the Department of Statistics, in the first quarter of 2021, courier sales revenue rose 43.6 percent. According to a survey conducted by Swedbank, in the first half of 2021, the bank's customers spent at least 754 million euros in Lithuanian e-shops. This amount increased by $55 \%$ compared to the same period last year.

The largest e-commerce centers in Lithuania, "pigu.lt" and "varle.lt", saw an 80 percent increase in turnover in the second quarter of 2020, during the first quarantine. Companies expanded their shopping cart: increased a range of children's goods, accessories, textiles, furniture, footwear, cosmetics, also launched to sell food products.

Since 2020, when the first quarantine was announced, the number of people who bought or ordered goods or services online has jumped 6.2 percent to 60.0 percent, while this indicator has been growing steadily in previous years, by about 5 percent each year.

Comparing 2021 data with the pre-pandemic period, most people aged 25-34 bought online (90.8percent). The number of buyers in the age group 35-44 increased especially (16.3 percent) and it makes up 81.9 percent of all persons in that age group. 86.9 percent of 16-29 year olds shop online. In 2021, 54.6 percent of 45-54 Lithuanians surveyed ordered or bought goods or services online at least once

According to the survey, in the main group (65-74), every sixth resident or 16.8 percent of this age group went shopping without leaving their home. According to the survey data, quarantine for online shopping in 2020 had the least impact on persons in the age group 55-64 (about 2percent). However, after the protracted restrictions in 2021, 34.1 percent of people of this age had already tried online shopping, i.e. 8.4 percent more than before the pandemic.

At the beginning of 2021, a survey of Lithuanian Internet users conducted by the research company "Gemius" showed that 83 percent of Lithuanians Internet users bought online in 2020 - a third did so several times a month. More than half, 56 percent, of the population said they bought online as a result of the pandemic. In addition, two-fifths of respondents admitted that their spending on online shopping through quarantine has increased. 27 percent of the population believe that by 2021 they will buy even more online.

1. The main factors determining online shopping are the age of consumers, online skills, convenience, reliability, enjoyment and other uncontrollable factors.

Research by foreign researchers has shown that the COVID-19 pandemic has changed consumer decisions and online shopping behaviour.

2. An analysis of the financial and other statistics of businesses involved in e-commerce shows that the COVID-19 pandemic and quarantine had an impact on turnover and profit growth, especially in the first quarter of 2021. After the release of quarantine restrictions, electronic sales revenues fell, but they still remained higher than in the pre-pandemic period.

3. After the analysis of the data of the e-commerce participants, of the Department of Statistics, of the research company "Gemius", it can be stated that the COVID-19 pandemic and quarantine had a significant impact on the decision of the Lithuanian population to buy online. This is especially evident in the surveys of individuals and financial data of e-commerce companies on 2021.

Keywords: e-commerce, consumer behaviour, COVID-19. 